\title{
Oriental Ecofeminism
}

\section{Contrasting Spiritual and Social Eco-femininity in Mitra Phukan's The Collector's Wife and Manjula Padmanabhan's Escape}

\section{Punyashree Panda \\ Panchali Bhattacharya}

Indian Institute of Technology

\section{Abstract}

As a theoretical conjecture, the inception of ecofeminism in the vista of oriental environmentalism can hardly be traced back beyond the present century. Ideologically, it concerns itself with the ceaseless persecution and consequent subjugation of both nature and women since these two are contemplated to be identical in terms of their propensity to nurture life. However, this supposition has its own diverse ramifications which have been probed by contemporary Indian English fiction writers from unprecedented frames of reference. The association of nature and a woman's pursuit for selfhood has been surveyed very exhaustively at the beginning of the twenty-first century by two eminent Indian women novelists-Mitra Phukan in The Collector's Wife (2005) and Manjula Padmanabhan in Escape (2008). The former, set in the highly realistic background of 1970-80s Assam insurgency, obliquely formulates a spiritual alliance between the natural world and the protagonist in terms of their interdependence to ensure existence, whereas the latter, a futuristic dystopia, recounts a social issue which concerns the quantitative and qualitative decline of women and nature correspondingly. The protagonists belong to completely different backgrounds and timezones, but both of them undertake a parallel mental voyage to unearth their true self, their respective identity as an individual in a world that is characterized by anomalies in environment as well 
as in humanity. In addition, the novelists also make an endeavor to study major eco-critical issues like "eco-ambiguity," "ecocide," and "ecophobia" which show the readers the way to interpret the texts through the lens of "environmental humanities" as well.

\section{Keywords}

identity crisis, Oriental ecofeminism, science fiction, social ecofeminism, spiritual ecofeminism 


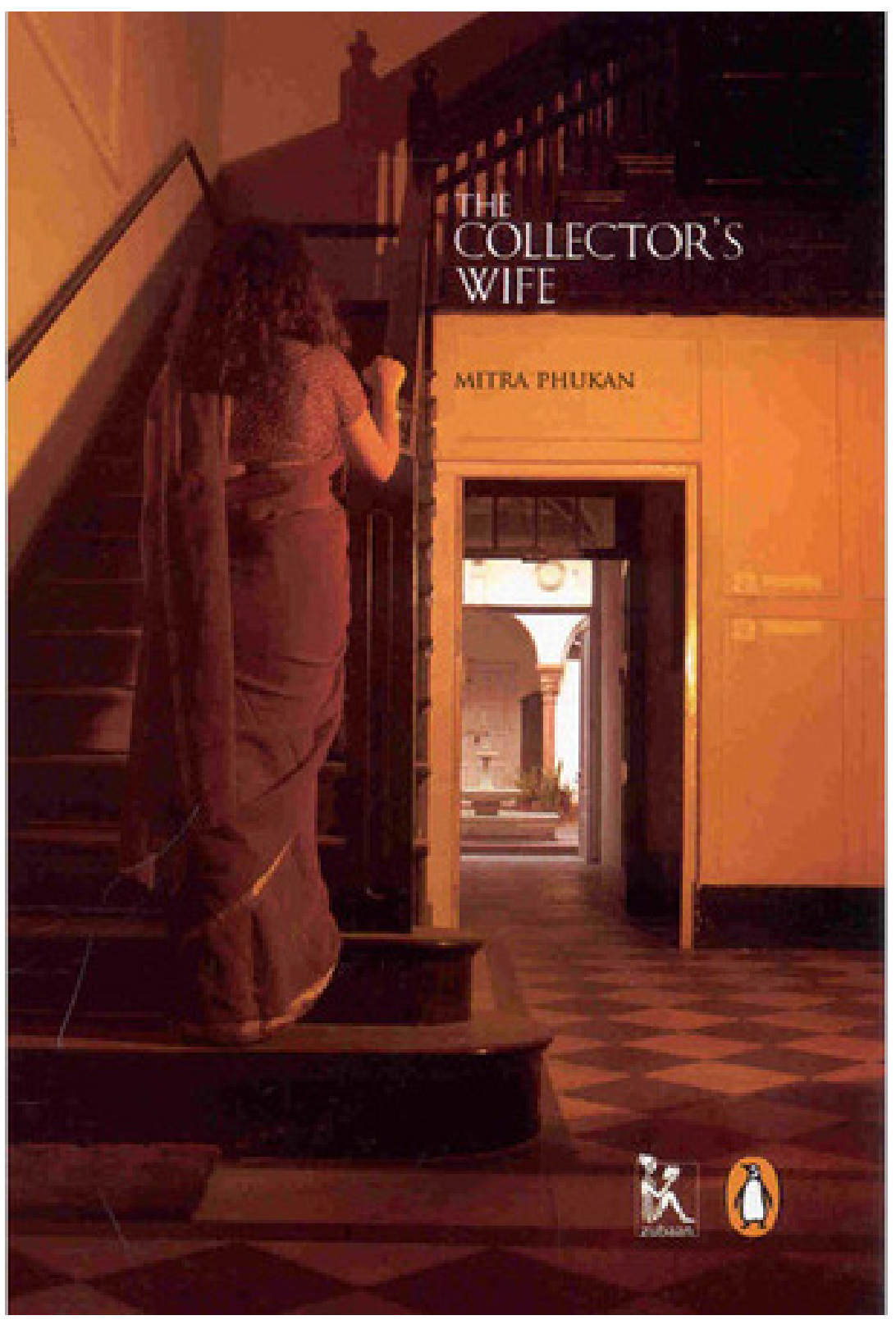

Fig. 1. Cover of The Collector's Wife by Mitra Phukan; https://zubaanbooks.com/ 


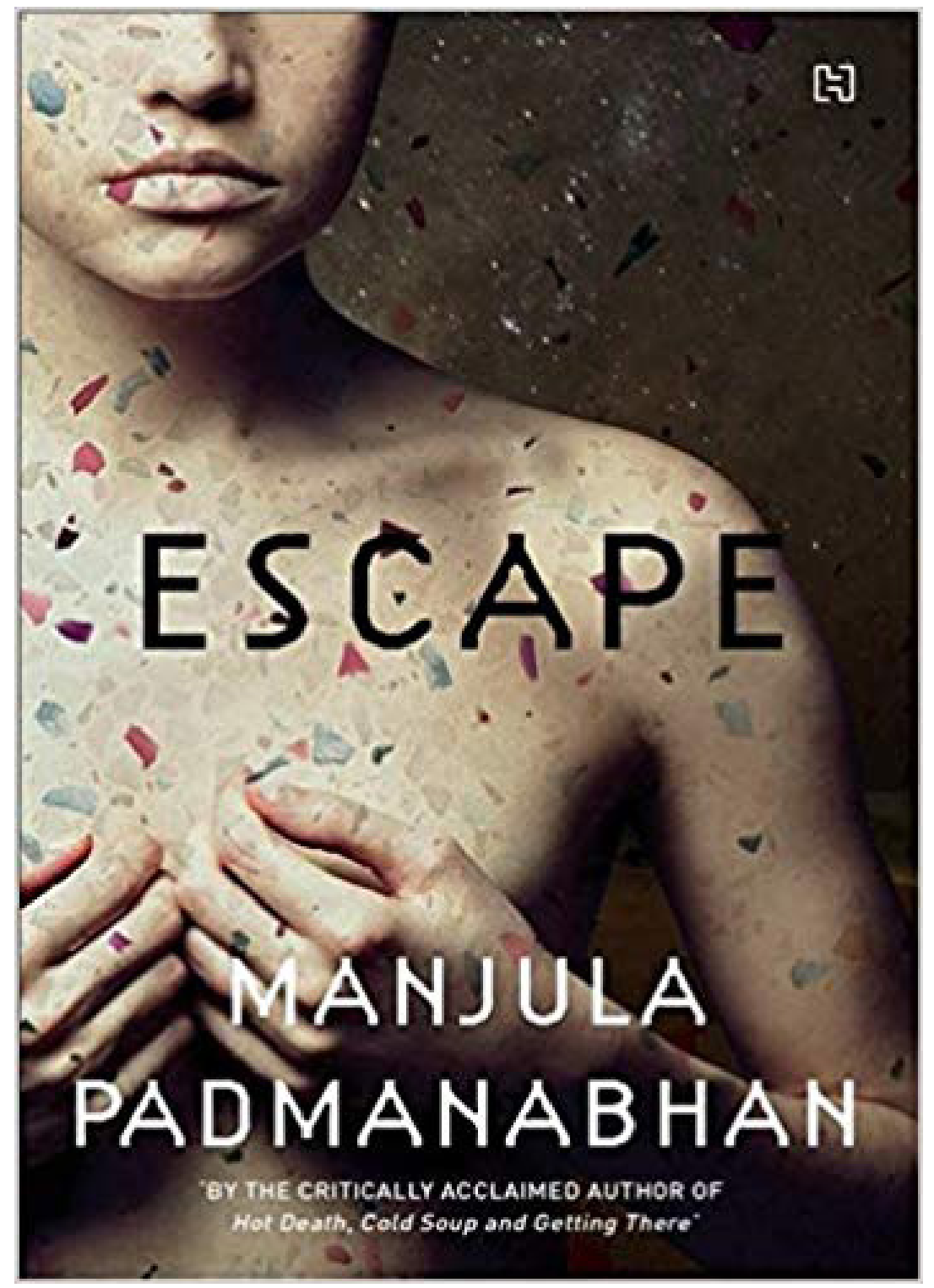

Fig. 2. Cover of Escape by Manjula Padmanabhan; https://www.goodreads.com/ 


\section{Introduction}

Derived from the Greek word "oikos," the term "ecology” concerns itself with the harmony of human, animal, and plant life on earth. It evokes a sense of celebration of the natural world. However, the advent of the twentieth century marks a colossal advancement and consequent maltreatment in the domain of science and technology which quite predictably wreaked havoc on the environment. The corresponding literary creations of this era also demonstrate an urge to address the alienation and exploitation of nature wrought by technology. In connection to this, a slow-paced radical ideology, popularly recognized as "ecocriticism" emerged, which "might succinctly be defined as a study of the relation between literature and environment conducted in a spirit of commitment to environmentalist praxis" (Buell 430). Cheryll Glotfelty, too, in her seminal work The Ecocriticism Reader: Landmarks in Literary Ecology, delineates the cultural criticism from the environmentalist point of view as "the study of relationship between literature and the physical environment" (xviii). In fact, ecocriticism is not merely about direct representations of environmental damage through literature; it is also about the whole array of our everyday life which reveals the implicit attitudes in our surroundings that have environmental consequences. Although the depiction of nature's blessings and sublimity has been integral to literature since antiquity, the endeavor to generate awareness through literary productions about the depletion of the environment due to unrestrained capitalism, excessive exploitation of nature, and atmospheric hazards is a relatively fresh addition. The tone and stance towards nature in most of the literary masterpieces coming from the oriental context have been largely panegyric; however, "worries of a lack of resources, of a decreasing number of species, of a booming human population, and of an overall place to live have been great concerns in the highly destructive civilization which we live" (Ambrosius 1). That is why the new millennium has exhibited an initiative among literary writers to engage their works with the destruction inflicted on nature by humanity. Such an addressing quite naturally facilitates the necessity of raising awareness about the deterioration of the environment. Nevertheless, the beginning of the twenty first century attributes 
prominence to a number of literary masterpieces that scathingly criticize the morbid lifestyle of the contemporary generation and put in question the sustainability of ecological harmony, thereby playing a major role in shifting human orientation from an anthropocentric view to a biocentric one.

\section{Development of Ecofeminism}

Towards the end of the twentieth century, the ecology movement mutually reinforced its goals with a number of other socio-economic apprehensions, such as race, class, gender, and colonialism, of which the one that is lately crafting the utmost stir is the integration of the two social movementsenvironmentalism and feminism-from which emerged "a new term for an ancient wisdom" (Mies 13)-Ecofeminism. According to Carol J. Adams, "[e]cofeminism addresses the various ways that sexism, heteronormativity, racism, colonialism, and ableism are informed by and support speciesism and how analysing the ways these forces intersect can produce less violent, more just practices" (1). In other words, as a doctrine, ecofeminism takes a standpoint that is starkly in contrast to the anthropocentric and androcentric approach toward human existence. For critics like Tollefsen, "ecofeminism is ecological because the preservation of ecosystems is a prime objective, and feminist on the basis that it offers up ways to recognize and counter male favouritism" (91). The theoretical exploration of "oriental ecofeminism" has gained prominence quite recently even though the revered tradition of respecting women and worshipping nature can be traced back a long way:

... the world is produced and renewed by the dialectical play of creation and destruction, cohesion and disintegration. The tension between the opposites from which motion and movement arises is depicted as the first appearance of dynamic energy (Shakti). All existence arises from this primordial energy which is the substance of everything, pervading everything. The manifestation of this power, this energy, is called nature Prakriti) 1. Nature, both animate and inanimate, is thus an expression of Shakti, the feminine and creative principle of the cosmos; in conjunction with the masculine principle (Purusha), Prakriti creates the world (Shiva 37). 
Oriental ecofeminism attempts to address ideas like nature, wilderness, natural science, and spatial environment. That is why a number of literary offshoots of the current century from the Indian sub-continent have drawn "on the insights of ecology, feminism, and socialism" to suggest that "the ideology which authorizes oppressions such as those based on race, class, gender, sexuality, physical abilities and species is the same ideology which sanctions the oppression of nature" (Gaard 1). However, according to Karen J. Warren, "[j] ust as there is not one feminism, there is not one ecofeminism or one ecofeminist philosophy. Ecological feminism has roots in the wide variety of feminisms . . . Ecofeminist philosophy extends familiar feminist critiques of social isms of domination to nature" (4). Ranging from early rural to the modern urban proposition, ecofeminism has branched itself in a number of distinct streams-radical or cultural ecofeminism, spiritual ecofeminism, social ecofeminism, ecofeminist theology, and so on. The ensuing discussion proposes to unravel a comparative study between the treatment of two of these branches-“spiritual ecofeminism” (Tollefsen 91) and "social ecofeminism" (Merchant, The Death of Nature 194) explored in the novels of two widely acclaimed Indian English authors-The Collector's Wife by Mitra Phukan and Escape by Manjula Padmanabhan respectively.

\section{Spiritual Ecofeminism in Mitra Phukan's The Collector's Wife}

The North-Eastern part of the Indian subcontinent is quite rich in biodiversity as it has an immensely rich archive of some rare species of flora and fauna, mineral resources and subsistence livelihood. Thus the literary fabrication coming from this part of the country, a region that is also a unique assortment of cultures, traditions, languages and dialect, will always be the most prominent propagator of the co-existence of the natural world with the human race in general and women in particular. Even though many of the predominant themes in the literary creations produced by the North-Eastern fiction and non-fiction writers are that of violence, insurgency, political upheavals, and social justice, the relationship between nature and man has invariably been a major thrust in those inscriptions. In a distinctive oriental ecofeminist tone, there has been a celebration of the beauties of nature and 
a depiction of people as intimately connected with the natural world. On the one hand, they promote the idea of living together peacefully with nature and maintaining a balance in the entire ecosystem; on the other, due to the recent growth-oriented development paradigm which is posing serious threat to ecology, there is a deep consternation in the writings regarding the degradation of environment and the condition of women. In the writings of most of the North-East authors, an ecofeminist perspective has always been used consciously to attain an identity-an identity for the creator, the protagonist, the people, and for the region in general.

One of the most prominent literary voices in English from North-East India, Mitra Phukan demonstrates a strong eco-consciousness and an equally sensitive attitude towards the insecurity of women spawned from the age-old legacy of deprivation in her novel, The Collector's Wife, one of the first generation novels in English written by an Assamese writer. In spite of portraying the violence and terror that characterize the troubled political situation in the small district town of Assam named Parbatpuri, the novelist does not shun from critically focusing at the representation of nature, landscape, and the attitude of the masses toward the environment. Along with this concern for nature, Phukan quite evocatively merges the identity crisis that a woman experiences in a world where insurgency and terrorist activities loom large. Narrated from the perspective of Rukmini Bezboruah, a part-time teacher of English literature in a semi-urban college who is also the District Collector's (DC's) wife, the novel recounts the experiences of the protagonist who lives a desolate life because of the assumed sense of superiority that normally characterizes the DC's wife. Being geographically as well as psychologically segregated from the residents of the small locality, Rukmini gradually seems to be unable to find her distinctiveness as an individual. The constant threat of extortion and kidnappings by the terrorist organization "Movement for an Exclusive Homeland," better known as MOFEH, and the political instability due to a full-blown insurgency keep Rukmini's husband, Siddharth, the Collector of the district town, constantly on the run. This obviously adds to the void in Rukmini's life. Childless even after ten years of marriage, Rukmini is thoroughly dissatisfied even with her vocation as a lecturer who "did not 
enjoy presenting the tortured soliloquies of Hamlet to small town teenage minds, or Jane Austen's polished prose to those whose knowledge of English grammar was, at best, merely adequate" (Phukan 27). However, seemingly unintentionally, Rukmini finds herself in due course getting involved in an adulterous relationship with a distant acquaintance, Manoj Mahanta, who to some extent tries to mend the emptiness in her life with his companionship and physical intimacy. A bond like this invariably generates a strong sense of culpability in Rukmini for betraying a ten-year-long relationship but in turn, she too comes to know about the perfidy that her husband, Siddharth, is perpetuating on her through his adulterous relationship with Rukmini's colleague, Priyam. In spite of such a development, Rukmini manages to reach a mental poise when the pristine beauty of the surrounding nature endows her with clarity and prudence, and thereby culminates her search for the self, an identity that will substantiate her existence as a self-contained entity. She gets an epiphanic vision towards life which comes to pass only when she allows herself to get immersed in the natural surroundings to which she has so long been associated with:

The complications and complexities of their lives, the hatred, the violence, the suspicion and pettiness that coloured Parbatpuri, were dwarfed in the face of this marvelous, all-encompassing melody all around her. And all she had done was to leave her house, take just a few steps down the road, in order to see things with such sudden clarity (Phukan 262).

The relationship that Rukmini shares with her husband after her revelation in the lap of nature is apparently depicted to be one of silence and detachment, but even then, the silence does not fall short to speak volumes, as both Siddharth and Rukmini come to realize the worth of life in a world that is ripped apart by hostility and demolition. Rukmini thus turns out to be a true envoy of "ecospirituality" that evokes the "manifestation of the spiritual interconnection between human beings and the environment ... [ [and which] engages a relational view of person to planet, soul to soil, and the inner to outer landscape" (Lincoln 228). The forest where she takes resort for a brief period of time to organize her thoughts hints at this eco-spiritual 
association. "The place was as peaceful now as any ancient sacred grove. The quietude settled softly on her, soothing her agitation ... As her focus shifted from herself to her surroundings, she became aware of the vibrant, lively atmosphere... This was a joyous celebration of life" (Phukan 261). Thus both Rukmini and the natural world that rears her, cast a silent yet positive effect on the people who encircle both of them. The final dénouement in Rukmini's life, however, surpasses all the troubles and tribulations that she has encountered so far, as the terrible insurgency-driven social situation snatches the lives of both her husband and her paramour, the father of her unborn child. In spite of being disgruntled with her subsistence, Rukmini nonetheless draws a healing sensation from her intricate bonding with nature and ultimately makes a decision that the reader hardly expects-the resolution to nurture the life that she is carrying in her womb. Through this decision of the protagonist, Phukan, in effect, undertakes an attempt to manifest Nature as a living entity and thereby touch upon the theme of fertility. Fertility stands for survival and sustenance and this substantial reference to fertility indicates the author's intention to show that both Nature and woman, no matter what catastrophe befalls them, are here to survive and remain fertile. This bestows upon the novel a sense of universality in spite of the specificity in time and place. Rukmini's sense of belonging and responding to the cosmos perhaps have some correlation to Ursula Heise's understanding of "sense of place" as illustrated in her book, Sense of Place and Sense of Planet: The Environmental Imagination of the Global. "Sense of place" refers to the particular experience of an individual in a particular place which gives the setting a special personality. In fact, in Phukan's novel, it is Rukmini's propinquity with the world of flora and fauna that escorts Rukmini to take up "the challenge . . . to shift the core of cultural imagination from a sense of place to a less territorial and more systemic sense of planet" (Heise 56). Thus she effortlessly comprehends her exact place in the universal ecosystem and thereby successfully apprehends the value of being able to procreate.

Despite the fact that the natural world has been invested with multifaceted dimensions in the literature coming from North-East India, there is hardly any acknowledgement to the reality that the region has also a long 
account of transforming and exploiting nature. Karen Laura Thornber, in her book, Ecoambiguity: Environmental Crises and East Asian Literatures, discusses environmentalist literature coming from the eastern part of Asia in which there is a celebration of the beauties of nature and the intimate association of the people with the natural world; but those writings have barely any reference to the devastation perpetuated on nature by the same masses. Mitra Phukan, in The Collector's Wife, very subtly touches upon a similar facet of ecoambiguity by providing a detailed description of the history of the small district town of Parbatpuri. She highlights the abuse of nature by presenting the contemporary scenario which necessarily involves dirt and squalor, an inevitable outcome of urbanisation. For them,

[t]he metaphor of the earth as a nurturing mother was gradually to vanish as a dominant image as the Scientific Revolution proceeded to mechanize and to rationalise the world view. The image of nature as disorder, called forth an important modern idea, that of power over nature (Merchant, The Death of Nature 2).

Living in the "residences-cum-offices perched on hillocks that lifted, symbolically as well as literally, high above the 'native' masses below" (Phukan 18), Rukmini had the rare dispensation to the "heart-stopping views of the surrounding landscape" (Phukan 19), which "cosmeticized Parbatpuri's dirt and squalor, while the abundant plant life that sprang up from every available surface, served to discreetly cover its numerous shanty-slums and run-down neighborhoods with a tracery of delicate green” (Phukan 21). The characters in the novel are depicted to be conscious of the necessity of natural preservation, but are at the same time not active enough to put their thoughts into action. Even a social activist like Priyam Deka, Rukmini's colleague in D.S. College, who has "several 'causes' to fight such as AIDS, the environment, and child prostitution" (Phukan 39) does not hesitate for a moment to crumple a used paper tissue and "toss it carelessly out of the window. It sailed some distance down the road and landed by the side, an incongruous, bright-pink scrunched up object amidst the mud and the slime" (Phukan 187). With a tinge of humour, the novelist draws attention to the 
hypocrisy of the environmental-activists of Parbatpuri and the Forum for Citizens' Rights who "periodically made noises about the alarming rise in the environmentally-hazardous practice of using non-bio-degradable bags, (but) the citizens of Parbatpuri always pestered their shopkeepers to give them a couple of extra bags free with every purchase that they made" (Phukan 33). Such a perfunctory stance brings into discussion the concept of "tokenism" since it focuses on the display of customary concern on the part of the citizens of this slowly developing town towards environment, camouflaging the innate attitude of sheer nonchalance.

Along with these environmental concerns, the novelist makes an attempt to lay a hand upon the threads of ecofeminism, too, but her treatment of the theory is exceptional. Though traditionally ecofeminism equates the oppression of women to the devastation of nature, Phukan's treatment of spiritual ecofeminism "draws on various expressions of 'nature religion' involving the worship of immanent forms of the feminine divine, one of the most significant traits of oriental ecofeminist concern. This is a source of women's empowerment as well as a strategy for environmental protection" (Tomalin 214). She offers a subtle layer to the conventional approach and lends an elevated status to her protagonist by equating Rukmini to nature, although not in terms of their oppression; rather she allots a spiritual association between Rukmini and the natural world. Such a treatment undoubtedly justifies Besthorn and McMillen's definition of "spiritual ecofeminism” which believes in ". . . the resacralization of Nature, of the divine feminine inherent in all living beings. It is seen as part of a process of reconnection, a re-establishment of ways of knowing and being in the world that have been lost in the history of patriarchal domination” (qtd. in Tollefsen 91). Unlike a radical ecofeminist who contends "that the dominant patriarchal society equates nature and women in order to degrade both" and "encourages the exploitation of women and nature for cheap labour and resources," Mitra Phukan turns out to be an oriental spiritual ecofeminist who "has roots in nature-based religions and goddess and nature worship as a way of redeeming both the spirituality of nature and women's instrumental role in that spirituality" (Miles, "Ecofeminism”). Whatever mental mayhem the protagonist 
goes through in the novel resonates in the natural world. That is why each stage in the life of the protagonist corresponds to the diverse phases of nature that surround her. Her infertility becomes synonymous with the scarcity in nature; the relief of her mental agony through her adulterous relationship is reflected in nature when it ushers rain to spurn the suffocation of summer. The tragedy in her life is also unfortunately invoked by nature when both her husband and the father of her unborn child fall victim to the insurgency and their death is facilitated by the topsy-turvy conditions in nature. But it is undoubtedly her inherent womanhood that enables Rukmini to come spiritually close to nature and realize the sacredness of humanity, her connection to everything living, and thereby accommodate herself accordingly. Thus nature forms an integral part of Phukan's writing in as far as the background and the stream of events are concerned. In fact, the landscape functions not merely as a framing device, setting, background or symbol, but as a presence that begins to suggest that the course of human action in the novel is implicated and determined through the flow of the natural world. To put it more succinctly, the novel bestows renewed spiritual sensitivity on the natural world, and thereby justifies the spiritual ecofeminist bent of the novelist for whom an individual's experiences of awe and wonder in relation to nature is what defines ecofeminism. Spiritual ecofeminism, for Phukan, is a form of "geopiety" which "connotes action and notions of responsiveness towards a place that is regarded as sacred ... a person's special attachment and reverence for particular places or locations in the environment: places that have specific, highly personal meaning" (Knowles 9). It is nothing but a divine perspective towards the immense beauty and elegance of life on earthnatural existence that is bequeathed with an ethereal and almost intangible connotation.

\section{Social Ecofeminism in Manjula Padmanabhan's Escape}

In contrast to the pragmatic account of Mitra Phukan, we have Manjula Padmanabhan's Escape which gives an elaborate shape to the form of postcolonial feminist dystopia. The novel very gracefully touches upon the issue of the alarming decline in the sex-ratio of an imaginary civilization, "a wasteland 
presided over by Generals who reject uniqueness and individuality as well as the natural processes of birth and death in favor of genetic engineering and cloning" (Dasgupta, "Future Imperfect"). It presents a horrifying vision of the future where women have been completely exterminated. Escape moves from its fundamental premise of the subjugation and exploitation of woman to the relationship between woman and modern state to a collective proposition of the communication between the individual and the nation-state in the era of technological precision and consumerist globalization. The setting can be quite distinctly interpreted as India from the detailing of some culturally and linguistically unique words like veena, lassi, paratha, bulbul etc. Meiji's uncles eat rotis and brinjal curry, bathe in rosewater, milk and steam, wear mulmul kurtas and pyjamas, eat paan from lotus-shaped containers and use spittoons. However, in spite of the numerous Indian references, it is quite evident that the country and government in Escape satirizes modern nationstates in general which demonstrate marked signs of the despotism of the dominant. The story of how a free country can become an absolute autocracy ruled by a collection of merciless Generals is a warning for modern-day democracies. The novel speaks of a nation where

... technology and a phobia of women have combined to create a country in which all females have been exterminated and a ruling class of cloned Generals keep a . . . grip of surveillance on the populace. Women are no longer needed for reproduction since men can clone themselves whenever they wish. They are not required for sex as homosexuality has replaced heterosexuality as the norm (Chandra, "Desire Unfulfilled").

Escape provokingly appropriates the style, motif, and references of the science fiction genre. According to Parvathi,

Manjula Padmanabhan belongs to that generation of Indian women writers in English who have boldly stepped out of conventions that define respectability to address issues of gender, woman, her body and its behaviour, its exploitation in a family and social setting . . . Manjula Padmanabhan has opened a fresh dialogue on a new angle of feminist concerns (136). 
Works of science fiction written by women have often seemed to be an imitation of the traditional women's fiction with an alteration in space and time: the "sweet, gentle, intuitive little heroine solves an interstellar crisis by mending her slip or doing something equally domestic after her big, heroic husband has failed" (Russ 88). Escape has often been considered as "one of the few works of modern Indian science fiction" (Joseph, "Manjula Padmanabhan's") since it opens "a room for plurality and multiplicity to provide the reader not only with entertainment but with tools to debate on post-humanism, environmentalism, gender, class and religion, among others" (Agraso, "Feminist Science"). In terms of vision, Padmanabhan has marked a paradigm shift from the science fictions of 1950 s and has successfully defended her claim made in the introduction to her short-story collection Kleptomania where she categorizes science fiction as a literary type which

... offers a writer the opportunity to go directly to the heart of an ironical or thought-provoking situation by setting up a theoretical world. It's a bit like writing a problem in mathematics, reducing reality to a tangle or pipes and cisterns or a group of three people travelling at varying speeds up a mountain, in order to reveal the relationships between matter, time and space (Padmanabhan viii).

A close analysis of the novel fairly predictably directs the reader to infer an obvious implication to the notion of "anthropogenic ecocide," where the populace of a particular territory devastate with their own hands the natural environment in which they dwell: "The word nation is made ugly on account of its association with nativity, with birth, with nature and, by association, with excess. Nature is excessive and I abhor it for that reason" (Phukan 80). Such a vile perception is further intensely reflected through the family of the three brothers, Eldest, Middle, and Youngest, who has very discreetly protected a young girl, Meiji, the only surviving woman in a land which has, with the aid of ultra-modern science and technology, banned each and every association of women whom they consider as "the Vermin Tribe," a community that is expected to be "servile, dumb and deaf" (Padmanabhan, Escape 237). just like the mechanical drones. The readers here get a glimpse of Margaret Atwood's 
The Handmaid's Tale where the women are forced to act as handmaids who are "de-sexed, dehumanised and are forbidden choice and desire. They are not supposed to think and feel" (7). In Escape, Meiji is kept on artificial hormonal supplements which has restricted her bodily development, and that is why, even at the age of sixteen, she is physically and psychologically stuck somewhere in her childhood. The solitary means of recreation that she has been sanctioned to rejoice is her game of role-playing through which she gives vent to her embryonic dilemmas vis-à-vis her way of life. The three brothers have made impenetrable arrangements in some secretive cell to guard their "treasure" from the incessant surveillance of the Generals but are still under constant threat of being discovered. In this context, Padmanabhan drops a minute hint of the concept of "ecophobia," precisely referring to the fear of getting acquainted with the natural surroundings advocated by David Sobel in his largely celebrated book Beyond Ecophobia: Reclaiming the Heart in Nature Education (1996) through Meiji's initial reluctance to familiarize herself with the real green world-

Meiji had rarely been out of doors. She could not remember ever having seen an open field ... She had never been directly connected to such a vast space. The urge to run back indoors to safety and familiarity was turning her legs to jelly ... The grass was wet with dew and clung to her as she moved through it. "I don't like this, Uncle," she said. "I don't. I want to go back" (Phukan 66-67).

As Meiji advances towards her puberty, her guardians apprehend the necessity of moving the girl to a place which might understand her worth, and thus begins Meiji's voyage with her youngest uncle through a terrain that has been annihilated by atomic radiation and is now nothing but a "smouldering wasteland" (Padmanabhan, Escape 25). Here Padmanabhan portrays in vivid detail a glimpse of that world which unrestricted ultramodern technology, if not checked immediately, might present us with in the near future "a featureless wasteland, with no cultivation to be seen, no farms, no villages" (Escape 112). The two wanderers, in the course of their journey, pass "through a region so toxic that birds used to fall out of the air, dead" 
(Escape 124) since "the air was thick with diesel fumes" (Escape 143). The reference to the Generals and their unintelligent soldiers named "Boyz" who at the moment dictate over the nation by maintaining a constant vigil on the activities of the inhabitants, instantaneously reminds the reader of George Orwell's literary masterpiece, Nineteen Eighty Four, where a similar "Dynamic Surveillance team" called "Big Brother" monitors the conduct of the citizens and "seeks power entirely for its own sake. It is not interested in the good of others; it is interested solely in power" (272). In short, they represent technology which when not controlled, "erase history, geography, whole generations of people" (Padmanabhan, Escape 125). Under the garb of imagination, Padmanabhan directs unflinching questions at the ignorance of the contemporary generation towards the issues of "the extermination of women, the cement-rot bacterium, the bombs" (Escape 324). In fact, according to a census report published in The Times of India on March 31, 2011, there has been a clear indication of "a continuing preference for male children over female children-the child sex ratio in 2011 is 914 female against 1000 male-the lowest since independence ... a matter of grave concern" ("India's Population"). However, an alarming situation like this can no longer remain exclusively limited to a particular geographical territory.

Both her uncle and Meiji undergo a route of self-discovery which confers upon them an understanding that is at once authentic yet unfathomable. The girl becomes conscious about her womanhood, a realisation that has remained uncharted because of her association with an all-male world. It is only after her alliance with the elements of the natural world that Meiji starts openly exhibiting the nurturing self of her existence: "You will climb out of this safe, underground seed case in which you have been germinating for so long, push your two little green leaves up out of the soil, raise your head to the sun and-thrive. That is what we all hope for you" (Padmanabhan, Escape 89). Through her, the novelist ascertains her conviction that it women who after all, are the carriers of human emotions, unlike the impassive "Boyz" and the Generals who inhabit the world of her narrative. That is why, in spite of leading a life that has throughout been associated with mechanical, emotionless drones, Meiji harbours emotions perhaps biologi- 
cally, just like her mother did by displaying an unprecedented valour when she did not hesitate even for a moment before burning herself alive, only to protect her little girl child. The world that is ruled merely by scientific domination and technological tyranny is certainly deficient in emotional exuberance. The young dog that Youngest hands over to Meiji at a certain point of their flight also brings forth her womanly instinct of fostering. During their stay in the City, when Meiji stumbles upon "slender-bodied and surgically enhanced transvestites, swaying on high heels, wearing clothes with plunging necklines" (Padmanabhan, Escape 384), she retorts with repulsion. She realises "that those boys are dressed in the way that I'm supposed to look" (Padmanabhan, Escape 386). Moreover, while undertaking a part of their journey on water, Meiji encounters a brutal murder in a desolate island where a man is literally burnt by a group of castaways in a mood of perverse pleasure, an incident that leads her to hurl the most crucial and relevant question that ultimately justifies the standpoint of the novelist:

This afternoon ... I almost jumped into the water near the island. I wanted so much to save that man. I hated leaving him behind like that . . . even though he didn't see us and no-one knows we were even there, we know and we can suffer the memory .... Is that how it is then? ... We help no-one and no-one helps us? (Escape 359)

Meiji's sense of concern for the dying man is not merely reflective of her feminine urge to save and nurture all life; it is also a definite cry for help for a society that is increasingly impatient with the needs and stories of the "other." Padmanabhan exhibits her uneasiness with this disturbing social trend and very subtly brings to the readers' attention the phenomenon of social ecofeminism which is "a coherent, rational, democratic, and libertarian alternative to mainstream ecofeminism” (Biehl 5). As a theory, social ecofeminism:

... accepts the basic tenet of social ecology that the idea of dominating nature stems from the domination of human by human. Only ending all systems of domination makes possible an ecological society, in which no states or capitalist economies attempt to subjugate nature, in which all aspects of human 
nature-including sexuality and the passions as well as rationality-are freed (Merchant, Radical Ecology 194).

Taking a cue from this definition, Padmanabhan indisputably evinces her anxiety regarding a social subject like female foeticide and the consequential decline in sex-ratio: "Were women always so unwanted in a country which is supposed to revere them? . . . A much quoted traditional blessing from the Atharva Veda states 'Let a female child be born somewhere else. Here, let a male child be born” (Aravamudan 50). Ernest Callenbach, in his influential novel, Ecotopia: The Notebooks and Reports of William Weston, speaks of an imaginary society where "what matters most is the aspiration to live in balance with nature, 'walk lightly on the land,' treat the earth as a mother" (32). In stark contrast to this perception of "Ecotopia," Escape stirs up Padmanabhan's struggle with a civic principle that in the long run will inexorably derange the environmental equilibrium of this green planet-

... I belong to a place that is no longer mentioned outside our borders. That's the price we paid for what was identified, by...the United Nations, as the 'most extreme crime against humanity our planet has ever yet acknowledged.' The very name of our country has been deleted from the record of the civilized world. So if they're going to recognize anyone from here, on compassionate grounds, it'll only be you. That's a woman. Not a man. Not any men.... You could say it's a kind of reverse justice (417-418).

Rupali Palodkar, in her article "Ecofeminism in India: Disappearing Daughters in Padmanabhan's Escape," beautifully sums up the social ecofeminist concern that involves a sinister and sordid disruption in the ecological as well as human world surveyed by Padmanabhan in her novel:

In Indian society, the ownership of women's body and sexuality and that of land (nature) has continued to rest with men since ancient times. Of all places in the world, it is in India that sex-selective abortions are practiced on a wide-scale ... There is a need to find an alternative to men's exploitation of the earth ... and to discover an ecologically sound way of life that would not threaten the existence either of the earth or of women. That is why women writers like Manjula Padmanabhan are turning to ecofeminist 
thinking and is writing about the consequences of degradation of nature and woman (60-61).

Thus the novel, Escape, through its socio-ecofeminist concern for both nature and women, emphasizes the necessity of self-awakening of the oppressed who desperately need to give voice to their perennial subjugation.

\section{Conclusion}

Taken together, The Collector's Wife and Escape reject the notion that human being's ". . . freedom and happiness depend on an ongoing process of emancipation from nature, on independence from, and dominance over natural processes by the power of reason and rationality" (Mies 6). On the contrary, the novelists, through the course of their narratives, consciously or unconsciously, substantiate the claim made by Kellert and Wilson which introduces "Biophilia Hypothesis," a concept seminal to the theory of "oriental ecofeminism." According to this concept, there has always been an inevitable attachment between human beings and other forms of living organisms. In fact, human beings are at all times driven by a subconscious biological "urge to affiliate with other life forms" (Kellert and Wilson 416) and with nature as a whole. The protagonists of the two novels under discussion also demonstrate an intrinsic inclination to acclimatize with the world that surround them, and that is why their search for individuality is perpetuated with authenticity only by coming in close proximity to the natural world. Even though both women belong to two completely different backgrounds and timezones, they are hinged at the point of a particular search-a search to identify one's own self. In the process of this probing, what they have in common is the struggle a woman undertakes and the pain she endures to realize her individuality, her identity as a human being, and the role nature plays in shaping and revealing that selfhood.

Such a treatment of the various environmental dimensions predominant in the oriental scenario by Phukan and Padmanabhan in their individual works bestows substance to the concept of "ecological humanities" which originated "through the confluence of simultaneous developments during 
the 1970s and the 1980s in departments of literature, philosophy, history, geography, gender studies and anthropology" (Emmett and Nye 3). Both the novels take into account an interdisciplinary study of several issues related to the natural world that has emerged in the last few years and thereby validate Carson's view:

We stand now where two roads diverge. But unlike the roads in Robert Frost's familiar poem, they are not equally fair. The road we have long been travelling is deceptively easy, a smooth super-highway on which we progress with great speed, but at its end lies disaster. The other fork of the road-the one less travelled by-offers our last, our only chance to reach a destination that assures the preservation of the earth (277).

However, the two novelists discussed here address ecofeminist concerns differently. While social ecofeminism distinguishes itself from spiritual ecofeminism in that the latter concedes a divine relationship between women and nature and wishes to unshackle them both at a go, the former envisions a society in which women surface as emancipated accomplices with the ability to restructure the oppressions inflicted by patriarchy and state on both environment and the female sex. Incidentally, the journey of both Meiji and Rukmini is loosely akin to the concept of "monomyth" or "the hero's journey" as propounded by Joseph Campbell in The Hero with a Thousand Faces, where "a hero ventures forth from the world of common day into a region of supernatural wonder: . . . the hero comes back from this mysterious adventure with the power to bestow boons on his fellow man” (23). The protagonists in both these novels undertake a voyage too, and in a decisive crisis, win and emerge as thoroughly transformed self-sufficient individuals. In the case of both Meiji who is part of a futuristic narrative in a dystopic world devoid of any touch of pragmatism and Rukmini who is a flesh and blood character belonging to a highly realistic milieu, the realization of containment is achieved only after both of them pay a heavy price for it-Rukmini by losing her husband and the father of her unborn child, and Meiji by thoroughly crushing her previous existence and association and becoming a full-grown woman with a thorough sense of her distinctiveness. The insight that both 
these women achieve comes from their respective alliance with the world of nature. Mother Nature offers solace to the confused, muddled souls of these women and thereby enables them to accept with regards whatever comes their way. Hence these two apparently dissimilar literary creations with a wide temporal disparity can be said to pay a collective homage to the infinite scope of ecological femininity through the fascinating characters of Rukmini and Meiji respectively. 


\section{Works Cited}

Adams, Carol, and Lori Gruen. Ecofeminism: Feminist Intersections with Other Animals and the Earth. Bloomsbury Academic, 2014.

Agraso, Paloma V. "Feminist Science Fiction from a Spiritual Ecofeminist

Perspective: Atwood, Butler, and Starhawk.” Informes USA, Instituto

Franklin-UAH, 2016. www.institutofranklin.net/wp-content/

uploads/2015/09/Informe-USA-Paloma-VILLAMIL_-ayuda-Benjamin-

Franklin-2015.pdf.

Ambrosius, Wendy. "Deep Ecology: A Debate on the Role of Humans in the

Environment.” UW-L Journal of Undergraduate Research, vol. VIII, 2005, pp. 1-8.

www.uwlax.edu/urc/jur-online/PDF/2005/ambrosius.pdf.

Aravamudan, Gita. Disappearing Daughters: The Tragedy of Female Foeticide. Penguin

Books India, 2007.

Atwood, Margaret. The Handmaid's Tale. Vintage Books, 1985.

Biehl, Janet. Rethinking Ecofeminist Politics. South End P, 1991.

Buell, Lawrence. The Environmental Imagination: Thoreau, Nature Writing, and the Formation of American Culture. Harvard UP, 1995.

Callenbach, Ernest. Ecotopia: The Notebooks and Reports of William Weston. Bantam Books, 1975.

Campbell, Joseph. The Hero with a Thousand Faces. Princeton UP, 1949.

Carson, Rachel. Silent Spring. Houghton Mifflin, 1962.

Chandra, Giti. "Desire unfulfilled.” Review of Escape by Manjula Padmanabhan. Biblio: A Review of Books, vol. 13, no. 11-12, Nov-Dec. 2008, p.12.

Dasgupta, Uma Mahadevan. "Future Imperfect." The Indian Express, 23 Nov. 2008. archive.indianexpress.com/news/future-imperfect/388809/.

Emmett, Robert S., and David E. Nye. The Environmental Humanities: A Critical Introduction. Massachusetts Institute of Technology P, 2017. muse.jhu.edu/ book/56296.

Gaard, Greta. Ecofeminism: Women, Animals, and Nature. Temple P, 1993.

Glotfelty, Cheryll, and Harold Fromm. The Ecocriticism Reader: Landmarks in Literary Ecology. U of Georgia P, 1996.

Heise, Ursula K. Sense of Place and Sense of Planet: The Environmental Imagination of the Global. Oxford UP, 2008.

"India's population rises to 1.2 billion: Census of India 2011." The Times of India, 31 Mar. 2011. timesofindia.indiatimes.com/india/Indias-population-rises-to-1-2billion-Census-of-India-2011/articleshow/7832520.cms. 
Joseph, V. Rositta. "Manjula Padmanabhan's Escape: Towards

a Universal Feminism.” Muse India-The Literary E-Journal, vol. 46, Nov.-Dec. 2012. www.museindia.com/Home/

ViewContentData arttype $=$ feature\&issid $=46 \&$ menuid $=375$.

Kellert, Stephen R., and Edward O. Wilson. The Biophilia Hypothesis. Island P, 1993.

Knowles, J. Gary. "Geopiety, the Concept of Sacred Place: Reflections

on an Outdoor Education Experience." Journal of Experiential

Education, vol. 15, no. 1, 1992, pp. 6-12. journals.sagepub.com/doi/

abs/10.1177/105382599201500101 ?journalCode=jeea.

Lincoln, Valerie. "Ecospirituality: A Pattern that Connects." Journal

of Holistic Nursing, vol. 18, no. 3, 2000, pp. 227-244. doi.

org/10.1177/089801010001800305.

Merchant, Carolyn. The Death of Nature: Women, Ecology, and the Scientific Revolution. Harper and Row, 1980.

---. Radical Ecology: The Search for a Livable World. Routledge, 2005.

Mies, Maria, and Vandana Shiva. Ecofeminism. Rawat Publications, 1993.

Miles, Kathryn. "Ecofeminism: Sociology and Environmentalism." Encyclopædia

Britannica, 2019. www.britannica.com/topic/ecofeminism.

Orwell, George. Nineteen Eighty Four. Secker and Warburg, 1949.

Padmanabhan, Manjula. Escape. Picador-Pan Macmillan India, 2008.

---. Kleptomania: Ten Stories. Penguin, 2004.

Palodkar, Rupali P. "Ecofeminism in India: Disappearing Daughters in

Padmanabhan's Escape." The Quest, vol. 25 no. 1, 2011, pp. 55-61.

Parvathi, B. "Critiquing Manjula Padmanabhan's Escape." The Critical Endeavour, vol. 15, no. 2, 2009, pp. 136-147.

Phukan, Mitra. The Collector's Wife. Zubaan-Penguin Joint List, 2005.

Russ, Joanna. "The Image of Women in Science Fiction." Images of Women in Fiction: Feminist Perspectives, edited by Susan Koppleman Cornillion, Bowling Green U Popular P, 1972, pp. 79-94.

Shiva, Vandana. Staying Alive: Women, Ecology, and Development. Zed Books, 1989.

Sobel, David. Beyond Ecophobia: Reclaiming the Heart in Nature Education. The Orion Society, 1996.

Thornber, Karen L. Ecoambiguity: Environmental Crises and East Asian Literatures. U of Michigan P, 2012. muse.jhu.edu/book/13594.

Tollefsen, Inga B. "Ecofeminism, Religion and Nature in an Indian and Global Perspective." Alternative Spirituality and Religion Review, vol. 2, no. 1, 2011, pp. 89-95. uit.no/Content/276140/Ecofeminism_Inga_2011.pdf. 
Tomalin, Emma. "Religion, Gender and the Environment in Asia: Moving Beyond the Essentialisms of Spiritual Ecofeminism?" Gender and Natural Resource Management, Livelihoods, Mobility and Interventions, edited by Bernadette P. Resurreccion and Rebecca Elmhirst. Earthscan, 2008, pp. 211-226.

Warren, Karen J. Ecofeminism: Women, Culture, Nature. Indiana UP, 1997. 